\title{
Using Data Envelopment Analysis in Credit Risk Evaluation of ICT Companies
}

\author{
Michaela Kavčáková, Kristína Kočišová \\ Faculty of Economics, Technical University of Košice, Slovak Republic
}

\begin{abstract}
The aim of the paper is to explore possibilities of diagnosis corporate credit risk through DEA and design an appropriate model for diagnosis of credit risk, which can be used in different sectors of national economy (e.g. agricultural, service sector or industry and innovation sector). The model differs from the conventional application of DEA because of variables selection and construction of production-possibility frontier. We illustrate application of models on sample 110 randomly selected companies during the 2013-2017 period. The reason for choosing the ICT companies is the fact that this sector is considered to be driving force behind the growth of the economy. The data has been obtained from Finstat. The results are divided into identification of 3 zones of corporate financial health with a different stage of credit risk. They show that DEA achieves a satisfactory value of a correct classification into the relevant zone (financial health, grey, and financial distress zone), but also the relatively high error rate of the DEA in the identification of companies in financial distress.
\end{abstract}

\section{Keywords}

Companies in the information and communication technology (ICT) services industry, credit risk, Data Envelopment Analysis, financial health.

JEL Classification: C14, G30

Kavčáková, M. and Kočišová, K. (2020) "Using Data Envelopment Analysis in Credit Risk Evaluation of ICT Companies", AGRIS on-line Papers in Economics and Informatics, Vol. 12, No. 4, pp. 47-60. ISSN 1804-1930. DOI 10.7160/aol.2020.120404.

\section{Introduction}

The companies in information and communication technology (ICT) services industry play an essential role in the economic environment as they have a significant impact on social and economic development. They change not only the interpersonal relationship but also the way the other industries do their business. As mentioned by Vanek et al. (2011), ICT development is driven by high dynamics that can even be surprising in many ways. The fast development of information and communication technologies lead to changes in job demand, roles, and general growth within the sector. According to Krausová (2018), the ICT sector is considered to be specific, as it is currently the driving force behind the development and growth of the economy, and at the same time represents a tool for transforming the traditional functioning of the society. That is why it is necessary to study the financial health of these companies and this way also the probability of bankruptcy of these companies.
Companies bankruptcy prediction is an evergrowing process of interest to investors or creditors, as well as borrowing institutions. As mentioned by Chaudhuri and Ghosh (2017) timely recognizing the companies' moving toward failure is often desired. Bankruptcy can be considered as the state where the company is not able to satisfy the debts and requests of the court of low to restructure its debts or liquidate its assets. A timely prediction can help to evaluate risks in order to prevent bankruptcy.

Business bankruptcies are an essential part of everyday economic life. They happen every day around the world. At present, setting up their own business is not complicated and very costly, and therefore it is established in Slovakia only on average 18500 per year. For this reason, it is crucial for the business itself to monitor its financial health and credit risk. Identifying and quantifying credit risk is essential in increasing the effectiveness, accuracy and consistency of risk management. It is a direct asset not only in credit approval but also in credit management, risk-based 
valuation, loan secularization and loan portfolio management.

Credit risk belongs to a group of fundamental financial risks that have a decisive impact on the success of various institutions. It is based on the uncertainty as to whether the counterparty will repay its (financial) liabilities promptly and at a fair amount, either due to inability or unwillingness to repay. It arises in the provision of loans, bank guarantees, project financing or investment transactions in financial derivatives. All transactions that are expected to be fulfilled at some stage (both financial and non-financial) from the external environment are subject to credit risk. This type of risk is the greatest risk for a bank in providing loans to other entities. For this reason, it is crucial for the bank to examine in detail the financial situation of the company, which plans to grant credit by analysing the financial health of the companies.

Evaluating the financial health, credit risk and determining the likelihood of bankruptcy is important for all sectors of the national economy, not just only for loans, but also for obtaining various state or EU funds and contracts. These funds and contracts are provided only to financially health companies that are not at risk of bankruptcy. A significant volume of grants is also intended for agriculture and forestry. Almost all support in Slovakia comes from the Rural Development Program, which invests in primary agricultural production, young farmers, construction of forest roads, purchase of forestry technology and much more. For this reason, it is very important for farmers and their strategic decision making and for policy makers to monitor their financial health. Various authors around the world address this issue within the agro-sector.

As mentioned by Kiaupaite-Grushniene (2016) the evaluation of financial health of agricultural enterprises is a important topic not only from an investor, but also from government and owner point of view. After accession to European Union, farmers are receiving significant subsidies from European and national budget, and those subsidies are intended to be provided only to financially healthy enterprises with future perspective of their sustainable economic performance. Therefore, there is a need to know how to distinguish te well performing companies from those who face the financial problems.

The question of financial healt of agricultural companies is also analysed by Zhao et al. (2008), who pointed to the fact that signalising of financial problems is an important element in the lenderborrower relationship that influences the cost and availability of debt capital, mostly from banks or from government, to agricultural borrowers. Therefore it is necessary to analyse the level of credit risk and the probability of bancrupty also in the companies from agricultural sector.

In Lithuania, Jedin and Stalgienè (2018) presented the likelihood of the Lithuanian family farms bankruptcy based on the economic size and type of farming by analysing financial indicators of farms. They used farm-level panel data for the year 2014-2016 from Farm Accountancy Data Network (FADN) and their research showed that more than $40 \%$ of small dairy farms had the high likelihood of bankruptcy in the year $2015-2016$, as well as $30 \%$ of medium and large cereals, oilseeds and protein crops farms in 2016.

Specific credit scoring model for agricultural loan portfolio, which reflects major risk characteristics of Indian agricultural sector, loans and borrowers and designed to be consistent with Basel II, was developed by Bandyopadhyay (2007). In this study he shown how agricultural axposures are typically can be managed on a portfolio basis which will not only enable the bank to diversity the risk and optimize the profit on the business, but also will strenghted banker-borrower relationship and enables the bank to expand its reach to farmers because of transparency on loan decision making process.

In US Breer et al. (2012) analyzed the probability of default for USDA Agriculture Resource Management Survey (ARMS) farms over time. They used a synthetic credit rating model to predict the probability of default for each ARMS farm sampled. The farms are classified according to farm type, gross sales class and by region to assess the financial health of each sector. Results of these analyses provide insights into which farms may be under financial stress and whether those farms under stress have common characteristics.

Within the Czech Republic Karas, Režňáková and Pokorný (2017) dealt with the issue of predicting bankruptcy of agricultural companies, who analysed the current accuracy of four traditional bankruptcy prediction models (a revised Z-score model, Altman-Sabato's model - the version with unlogged predictors and the version with logged predictors, model IN05) in the field of agriculture. Their results showed that these models are less accurate in this field in comparison with the original results and state, that this motivates the effort of deriving new models that would be specially developed 
for agriculture business.

Currently, there are several models based on which a bank can determine whether a borrower is financially healthy or on the verge of bankruptcy. Financial health is a characteristic of the financial condition of those companies that show favourable proportions between the various aspects of their finances. A financially healthy company does not show any signs of jeopardizing its continued existence; from its condition, it can be assumed that it will not be insolvent in the near future. Indeed, such an undertaking shows sufficient profitability and adequate coverage of the risks of indebtedness. Based on several methods, such as Altman's Z-score, Kralick's Quick test, Beaver's model, IN indices, according to the achieved values of companies are classified into three zones, namely the zone of financial health, so-called grey zone and bankruptcy zone. These methods are called bankruptcy and creditworthy models.

According to Kotulič et al. (2007), models based on empirical-inductive indicator systems are used to predict the financial distress of an enterprise, using, in particular, the following methods:

- one-dimensional discriminatory analysis - mathematical-statistical method, which predicts the financial distress of a company using a single indicator (e.g., Beaver's model);

- multidimensional discriminatory analysis - also a mathematical-statistical method which predicts financial distress using a set of multiple indicators, with different weights assigned to these indicators (e.g., Altman's Z-score, IN indexes);

- scoring method - predicts the financial development of the company using scales, which are usually determined by expert methods (e.g. Kralick's Quick test).

One of the most frequently used traditional models is Altman's Z score (Altman, 1968), which belongs to the group of multidimensional bankruptcy models. This test is based on empirical data on failed companies over the past five years before bankruptcy and data for successful companies over the same period. Subsequently, he used Multiple Discriminatory Analysis to determine the ratios that characterize both the current financial situation of the companies and their development. The essence of this analysis is to find a linear combination of indicators that best distinguishes companies from bankruptcy and prosperity. One of the strengths of this model is that it allows for simultaneous consideration of several financial variables on the purpose of developing a bankruptcy prediction model. Also, it highlights factors contributing to a company's financial health and uncovers emerging trends that indicate improvements or deterioration in financial condition. On the other hand, the test uses unadjusted accounting data - it uses data from relatively small firms, and it uses data that is around 60 years old, or the test's predictive ability dropped off considerably from there with only $72 \%$ accuracy two years before failure, down to $48 \%$, $29 \%$, and $36 \%$ accuracy three, four, and five years before failure, respectively.

Beaver was one of the first authors, who analyse the company's financial health. His model is called the Beaver's model (Beaver, 1966), and it is based on the one-dimensional discriminatory analysis. The main disadvantage of this type of models is the fact that the same company can be included in the group of financially healthy, but also in the group of companies in financial distress based on different indicators. The authors try to solve this shortcoming by using the above-mentioned multidimensional discrimination analysis.

The last traditional model that we are going to mention belongs to the third group of traditional models used to assess the financial health of the company, namely Kralick's Quick Test (Kralicek, 1993). This model is often used mainly in Europe, and it is a kind of transition between one-dimensional and multidimensional models. From each significant area of analysis, such as stability, liquidity, profitability and economic outcomes, he used one selected indicator and created a point scale. The final score for the entire test is calculated as the average of the marks achieved for each indicator.

The main disadvantage of the all mentioned models is that the connection between the value of financial ratios of bankrupt and likely will change over time as obsolete and outdated. They need to be redesigned to the current economic situation, and each country should modify main models to its own conditions.

Many authors have applied these mentioned traditional models in their research. Some of the authors also modified them, such as Káčer et al. (2019), who investigated the classification performance of the re-estimated Altman's Z-score model for a large sample of private SMEs in Slovakia. They have found that even though the model with re-estimated coefficients achieves 
better discrimination performance, it is not statistically different from the revised Z-score model. Altman's Z-score was compared with other models, for example, Bod'a and Úradníček (2019), who compared it with CH-Index and G-Index, Ékes a Koloszár (2014) compare it with logistical regression and neural networks or Vavřina et al. (2013) with logit models, DEA and production function-based economic performance evaluation. The approach of one-dimensional discriminatory analysis through Zmijewski's X-score have examined, for example, AlAli et al. (2018). The results obtained from this study have shown that companies working in that sector tend to have a healthy financial position, and they are on the safe side when it comes to bankruptcy risk. Husein, Pambekti (2014) or Aminian et al. (2016) have analysed the accuracy of the model of Altman's Z-score, Springate model, Zmijewski's $\mathrm{X}$-score, and Grover model as the best predictor of financial distress. The results of first mentioned authors have shown that the model of Zmijewski's $\mathrm{X}$-score is the most appropriate model to be used for predicting the financial distress because it has the highest level of significance compared to the other models. Aminian et al. (2016) concluded that the Grover model (Grover and Lavin, 2001) compared to the models of Altman's Z-score, Springate model and Zmijewski's X-score have shown better results. Since investors are always looking for knowledge the suitable situation for investment, and managers are interested in assessing the weaknesses and future threats and taking the necessary decisions in the face of these threats, they have suggested that the use of the Grover model as a tool for predicting bankruptcy or continuity of the companies and accordingly to make rational decisions.

However, these methods are outdated, and therefore scientists are trying to apply alternative methods that could better reflect the situation of the company in the current conditions. The multidimensional business performance environment is very attractive for the application of methods such as Data Envelopment Analysis (DEA), which takes into account both quantitative and qualitative information in the analysis. Data Envelopment Analysis is used to evaluate the technical efficiency of homogeneous units (Decision Making Units - DMU). It is a non-parametric method which belongs to a group of mathematical methods based on linear programming. This method aims to divide the surveyed objects into efficient and ineffective according to the size of inputs consumed and the number of outputs. DEA compares these objects to the best one.

The basis of DEA models is the so-called production-possibility frontier that is made up of all acceptable combinations of inputs and outputs. This frontier is determined by the production possibility curve, which determines whether or not the investigated unit is effective. The unit is effective if it lies at the production possibility curve. If it does not lie on this border, it is inefficient, and it is necessary to adjust the size of its inputs or outputs. By using DEA models, we can determine how to adjust these inputs or outputs in order to become an effective unit. Another basic term when using DEA is a Decision-Making Unit (DMU), which means the subject being evaluated in which the transformation process is taking place - the process of converting inputs to outputs.

DEA models can be classified according to different aspects:

- depending on how many inputs and outputs we are considering within the unit under review (evaluation of units with one input and one output, evaluation of units with two inputs and one output, evaluation of units with one input and two outputs, evaluation of multi-input and multi-output units);

- according to the orientation of the model (input-oriented, output-oriented, nonoriented);

- depending on whether they are based on the Constant Returns to Scale (CRS) assumption, the known Charnes-CooperRhodes (CCR) model (1978), or the models based on the Variable Returns to Scale (VRS), e.g. Banker-Charnes-Cooper (BCC) Model (1984);

- radial (CCR model, BCC model and radial DEA models to calculate the so-called superefficiency) and non-radial models (they monitor disproportionate changes in inputs and outputs for efficiency - ADD model of Charnes et al. (1985), Slack Based model (SBM) of Tone (2001)).

The most well-known scientist dealing with the application of DEA to various areas of the economy is prof. Paradi from the University of Toronto. This article will be based on his 2004 publication. In Slovakia, Mendelová and Bieliková (2017) used DEA to assess the financial health of industrial enterprises in Slovakia and compare the results with logistic regression and decision trees, inspired this publication. 
Table 1 shows an overview of the studies applying DEA to evaluate corporate financial health or credit risk. Beside studies mentioned in Table 1, there are also many studies dealing with application of DEA in other sectors of national economy, for example in agricultural sector. For example, Bányiová, Bieliková and Piterková (2014) used DEA approach for corporate failure prediction of the agriculture sector. Their findings demonstrate aspects of application alternative DEA approach as a corporate prediction tool, and the ways of identification enterprises with high chance of potential bankruptcy.

Also Janová, Vavřina and Hampel (2012) also dealt with the issue of evaluating the financial health of companies through the DEA method, who discussed the possibility of application of recent results in DEA bankruptcy prediction models in a specific field of agribusiness. According to their results they concluded that the small test case study provides them with promising numbers. In their future research, further validation calculations using a larger dataset will be done.
In studies from Table 1, the authors have used different types of DEA models, and also have chosen different indicators as inputs or outputs to the model. For example, Paradi, Asmild and Simak (2004) used a different combination of total assets, working capital, earnings before income, tax, depreciation and amortization, retained earnings, shareholders equity, total current liabilities, interest expense, cash flow from operations, the stability of earnings and total liabilities as inputs and outputs. Feruś (2008) as inputs set daily return indicator and total liabilities indicator, and as outputs set net profit indicator, return on assets, return on equity and liquidity ratio. Mendelová and Bieliková (2017) chose the most frequently used indicators in the DEA model. As inputs were set liquidity 3, level of net working capital, liquidity from cash flow, self-financing coefficient, EBITDA revenue share, return on assets, operating return on sales and financial return on assets and as outputs set the maturity of short-term trade payables, total debt, long- term debt, cost ratio of economic activity

\begin{tabular}{|c|c|c|c|c|c|}
\hline Name/s & Year & Country & Model & Aim of work & Results \\
\hline Feruś & 2008 & Poland & basic DEA & $\begin{array}{l}\text { A new procedure of forecasting } \\
\text { credit risk to companies in the } \\
\text { Polish economic environment. }\end{array}$ & $\begin{array}{l}\text { The DEA method facilitates forecasting financial } \\
\text { problems, including the bankruptcy } \\
\text { of companies, in Polish economic conditions, } \\
\text { and its efficiency is comparable to or even greater } \\
\text { than that of the approaches implemented so far. }\end{array}$ \\
\hline $\begin{array}{l}\text { Sueyoshi, } \\
\text { Goto }\end{array}$ & 2009 & USA & DEA-DA & $\begin{array}{l}\text { Discuss methodological strengths } \\
\text { and weaknesses of DEA and DEA- } \\
\text { DA from the perspective } \\
\text { of corporate failure. }\end{array}$ & $\begin{array}{l}\text { DEA is a managerial tool for the initial } \\
\text { assessment of corporate failure and DEA is } \\
\text { useful for busy corporate leaders and financial } \\
\text { managers; in contrast, DEA-DA is useful for } \\
\text { researchers and individuals who are interested } \\
\text { in the detailed assessment of bankruptcy and its } \\
\text { failure process in a time horizon. }\end{array}$ \\
\hline $\begin{array}{l}\text { Xin, Hoe, } \\
\text { Siew }\end{array}$ & 2019 & Malaysia & $\begin{array}{l}\text { inverse- } \\
\text { like DEA }\end{array}$ & $\begin{array}{l}\text { Propose a method framework } \\
\text { to estimate operational efficiencies } \\
\text { and potential income gains } \\
\text { considering the credit risk } \\
\text { for banks. }\end{array}$ & $\begin{array}{l}\text { The potential income gain can be estimated } \\
\text { by the proposed inverse-like model credibly. }\end{array}$ \\
\hline
\end{tabular}

Source: prepared by authors 
and interest cost ratio. As can be seen, all the mentioned authors used indicators that represent the main areas of company performance, namely, the area of liquidity, profitability, activity and indebtedness. In this paper, we will select indicators as inputs and outputs to the DEA model based on the procedure described in the following section.

Our contribution to the literature can be defined as follows. First, unlike most of the previous papers using one-year data, we focused on analysis ICT companies during the 2013-2017 period. Second, we do not apply the traditional models. However, we try to explore the possibilities of diagnosis corporate credit risk through Data Envelopment Analysis (DEA) method and design an appropriate model for the diagnosis of credit risk in the selected sample of companies.

\section{Materials and methods}

In this paper, we are going to use Data Envelopment Analysis method to evaluate the credit risk of selected companies. The selection of relative variables can be made based on a number of methods such as comparing box graphs, MannWhitney test, t-test, correlation analysis, or this selection can be made based on expert knowledge of the model creator or comparison of financial ratios between groups of companies in financial health and financial distress.

We have decided on the following procedure for determining inputs and outputs to the DEA model - inspired by Mendelová and Bieliková (2017):

1. multicollinearity elimination,

2. Mann-Whitney test,

3. find outliers,

4. distribution of indicators into DEA inputs and outputs.

According to Kassambara (2018), in multiple regression, two or more predictor variables might be correlated with each other. This situation is referred to as collinearity. Multicollinearity is an extreme situation, where collinearity exists between three or more variables, which means that there is redundancy between predictor variables. In the presence of multicollinearity, the result of the regression model is unstable. As mentioned by Kassambara (2018), multicollinearity for a given predictor can be assessed by computing a score by a variance inflation factor (VIF), which measures how much variance of the regression coefficient is inflated due to multicollinearity in the model.

Alin (2010) present the formula to calculate VIF for each variable:

$$
V I F_{i}=\frac{1}{1-R_{i}^{2}} \text { for } \mathrm{i}=1,2, \ldots, \mathrm{k}
$$

$R_{i}^{2}$ is the coefficient of multiple determination of $x_{i}$ on the remaining explanatory variables.

James et al. (2014) stated that the smallest possible value for VIF is 1, which indicates the complete absence of collinearity. Typically in practice, there is a small amount of collinearity among the predictors. As a rule of thumb, a VIF value that exceeds 5 or 10 indicates a problematic amount of collinearity.

The second step is the application of the MannWhitney test. The Mann-Whitney test, which is also known as the Wilcoxon rank-sum test, is a nonparametric test that allows two groups or conditions or treatments to be compared without making the assumption that values are normally distributed (Mann and Whitney, 1947; Wilcoxon, 1945).

Hart (2001) summarized the important points:

- The Mann-Whitney test is used as an alternative to a t-test when the data are not normally distributed.

- The test can detect differences in shape and spread as well as just differences in medians.

- Equally important differences in shape often accompany differences in population medians.

- Researches should describe the clinically important features of data and not just quote a P-value.

McKnight and Najab (2009) stated that the Mann-Whitney $U$ is intended to determine if two groups (e.g. samples "a" and "b") come from the same population (p), which is a null hypothesis significance test stipulating that both samples are subsets from the same population (i.e., H0: $(a, b) \subseteq p$ ). To test the null hypothesis, we first combine observations from two groups into a single group and rank the scores from 1 to $N$, where $N$ is the total sample size $\left(n_{a}+n_{b}=N\right)$. After ranking, the procedure divides the rank scores by group and computes a sum score for each group $\left(T_{a}\right.$ and $\left.T_{b}\right)$.

$$
\begin{aligned}
& \text { If } n_{a}>n_{b}: U=T_{a}-\left(n_{a}\left(n_{a}+1\right)\right) / 2 \\
& \text { If } n_{b}>n_{a}: U=T_{b}-\left(n_{b}\left(n_{b}+1\right)\right) / 2
\end{aligned}
$$


The U statistic has a discrete or uniform distribution that provides us with the ability to define a critical value, assign a probability to that value, and then test the null hypothesis. A critical value represents a probability level (typically .05). If the U statistic is greater than the critical value, then we reject the null hypothesis with the inference that both samples do not come from the same population.

Within the third step, we want to find out the outliers. According to Bogetoft and Otto (2011), outliers are firms that differ to a large extent from the rest of firms and therefore may end up being badly captured by the model or having too large an impact on the model. Outliers are often thought to be particularly troublesome to DEA because an outlier helps to span the frontier and may have a significant impact on the evaluation of several other firms.

The fourth step includes the distribution of indicators into DEA inputs and outputs. Financial indicators whose low value of the average indicates the company's financial problems in the future will be included in the group of inputs and financial indicators, whose high value of the average indicates the company's financial problems in the future, will be included in the group of outputs. In other words, the financial indicators that represent the financial strength and solvency of the company are selected for the inputs, and the financial indicators that represent the financial instability and insolvency of the company are chosen for the outputs.

After the mentioned steps, we apply the Data Envelopment Analysis to analyse the financial health of ICT companies. According to Mendelová and Bieliková (2017) construction, the production possibility curve consists of two steps:

- The production possibility curve is constructed on the basis of a whole sample of $n$ companies. In this way, we identify businesses that create the production possibility curve. These companies will be considered to have a relatively high probability of their future financial problems.

- From the dataset, those businesses that formed the production possibility curve in the first step are omitted, and another production possibility curve is constructed again on such a reduced dataset. In this way, the negative impact of potential outliers is partially eliminated, and those businesses that create the production possibility curve at this stage are considered to have some probability of their future financial problems.
However, this probability is relatively lower than that of those companies, that created the production possibility curve in the first step.

The authors used Altman's (1968) identification of the resulting three zones in this model:

- $\quad$ Financial Distress Zone: Contains companies that created the production possibility curve in step 1, i.e. companies with a relatively high probability of future financial problems.

- Grey Zone: Contains businesses that created the production possibility curve in step 2, i.e., businesses with a lower probability of future financial problems.

- Financial Health Zone: Contains companies that did not create a financial distress frontier in any of the previous two steps, i.e., financially healthy businesses.

We have decided that the ADD model for the VRS condition (Charnes et al., 1985) will be applied to quantify the distances of companies from the production possibility curve because it is not necessary to select the input or output orientation of the model. ADD model for the VRS condition for company $o, o \in\{1, \ldots, n\}$ is:

$$
\begin{gathered}
\max _{s^{-}, s^{+}, \lambda} e^{\prime} s^{-}+e^{\prime} s^{+} \text {under conditions: } \\
s^{-}=x_{0}-X \lambda \\
s^{+}=Y \lambda-y_{0}, \\
\lambda \geq 0, s^{-} \geq 0, s^{+} \geq 0, \\
e^{\prime} \lambda=1
\end{gathered}
$$

where

$n$ is the number of rated companies,

$X m \times n$ is a matrix of $m$ inputs of $n$ companies,

$Y_{s} \times n$ is a matrix of $s$ outputs of $n$ companies,

$e^{\prime}$ is a row unit vector with all components equal to 1 ,

$x_{0}$ is column vector $\mathrm{m}$ inputs of the company $\mathrm{o}$,

$y_{0}$ is column vector s outputs of the company o,

$s^{-}$is vector m slips of inputs of the company o,

$S^{+}$is vector s slips of outputs of the company o,

$\lambda \in R^{n}$ is a vector of weights, which connect inputs and outputs.

Let $\left(s^{-*}, s^{-*}, \lambda^{*}\right)$ be the optimal solution to the (3). Then the company o creates a frontier of financial distress in case the values of slips of inputs and outputs are zero, which means that $s^{-*}=0$ and $s^{+*}=0$. 
To assess the competence of this model, we classified the total number of $\mathrm{n}$ rated enterprises into six groups.

Group A companies in financial distress included in the financial distress zone

Group B companies in financial distress included in the grey zone

Group C companies in financial distress included in the financial health zone

Group D companies in financial health included in the financial distress zone

Group E companies in financial health included in the grey zone

Group F companies in financial health included in the financial health zone

The companies classified in groups A and F can then be considered as correctly classified. The companies classified in groups B and E can be considered as neutrally classified, and the companies classified in groups $\mathrm{C}$ and $\mathrm{D}$ can be considered as misclassified. Altman (1968) stated that group D is Type I Error, and group C is Type II Error.

Numbers of companies classified into group $\mathrm{i}$ we marked as $n_{i}, i=A, B, C, D, E, F$.

Index of correct classification $I_{C C} \in[0,1]$ is

$$
I_{C C}=\frac{n_{A}+n_{F}}{n}
$$

index of neutral classification $I_{N C} \in[0,1]$ is

$$
I_{N C}=\frac{n_{B}+n_{E}}{n}
$$

and index of incorrect classification $I_{I C} \in[0,1]$ is

$I_{I C}=\frac{n_{C}+n_{D}}{n}$

Whereas $\sum_{i=A}^{F} n_{i}=n$, it must be true that $I_{C C}+I_{N C}+I_{I C}=1$. The best situation is when values of $I_{C C}$ are high, and values of $I_{I C}$ are low.

The content of the following part of the article is an illustration and evaluation of the application of the above proposed DEA procedure for the case of Slovak ICT companies in the period 2013-2017. As it was mentioned in the introduction part ICT sector is considered to be specific, as it is currently the driving force behind the development and growth of the economy, and at the same time represents a tool for transforming the traditional functioning of the society. That is why it is necessary to study the financial health of these companies and this way also the probability of bankruptcy of these companies. In order to take into account, the potential differences that may exist between different sectors in the economy, only one sector of the economy was selected for analysis, the sector of Information services (SK NACE 63000). Due to the comparability of financial statements and subsequent quantification of financial indicators, only those companies that belonged to small, medium and large entities according to Slovak legislation were included in the analysis (microenterprises were not included due to differences in the structure of financial statements). We have used the Finstat's dataset of financial indicators to get the list of companies that we are going to explore, as well as to obtain the necessary data to calculate the mentioned model.

Out of the total number of 69 indicators calculated separately for each company, we have selected 27 of them. The indicators that were not mentioned by the majority of companies (less than $50 \%$ ) were removed from the database.

We have filtered the sample feed to include companies:

- not cancelled,

- $\quad$ earning more than $0 €$,

- $\quad$ which have available data for the 2013-2017 period.

A company in financial distress was considered to be a company that in next year met the criterion of defining a company in extension according to the valid legislation of the Slovak republic, i.e., the value of its payables exceeded the value of its assets, respectively the company reported a negative value of equity.

\section{Results and discussion}

All calculations, including quantification of the ADD DEA model, were performed in program R (specifically RStudio). We have used the following packages:

$$
\begin{array}{ll}
\text { - } & \text { faraway, } \\
\text { - } & \text { readxl, } \\
\text { - } & \text { deaR. }
\end{array}
$$

First of all, we have had to eliminate multicollinearity between indicators in order to exclude those indicators that provide relatively the same type of information. For this purpose, those indicators were excluded from the analysis for which a relatively high degree of correlation with other indicators was recorded $-\mathrm{VIF} \leq 10$.

Then we have performed the Mann-Whitney test of two independent selections to select those indicators whose values for healthy companies 
differ significantly from those for companies in bankruptcy according to equity - p-value less than .05 .

As mentioned in the previous section, the occurrence of outliers can cause significant problems in the construction of the financial distress line. For this reason, our next step was to remove them. We have removed outsiders separately for healthy companies and separately for companies in bankruptcy according to equity because if we removed outliers regardless of whether they belong to the group of healthy or bankrupt companies according to equity, the analysis would remove bankrupt companies because those would consider them as outliers.

At the end of the pre-preparation of data for the DEA and the determination of inputs and outputs, we calculated the averages for the indicators that we had left. The values of these averages, as well as the results of the MannWhitney test, are shown in Table 2.

The result of the whole previous process is three inputs and four outputs, which we will use in the DEA analysis.

Before that, we have randomly selected 100 financially health companies and ten companies in financial distress according to equity for each year. The reason is that in this article, we want to compare the success of the DEA for the evaluation of the financial health of companies for five years and compare it with each other in this period.

We apply Data Envelopment Analysis as a tool for evaluating the financial health of companies. The success of diagnosing the financial health of Slovak ICT companies using the proposed two-step procedure is demonstrated in Table 3.

The overall financial situation of the company was assessed on a scale of three zones (financial health zone, grey zone, financial distress zone) with different degrees of the threat of financial distress over a one-year time horizon.

We have applied step 1 of the proposed model of Mendelová and Bieliková (2017), creating a production possibility curve that represents the financial distress zone and was made up of companies with the highest probability of future financial problems. Step 2 identifies the companies in the grey zone, which means that there is less probability of future financial problems.

The production possibility curve which represents financial distress in $2013(2014,2015,2016,2017)$ was formed by $7.27 \%(4.55 \%, 6.36 \%, 9.09 \%$, $8.18 \%$ ) of companies from the entire subset of 110 Slovak IT companies, which was calculated as

percentage of companies that create the production possibility curve in first step

$=\frac{\text { number of companies in group } A+\text { group } D}{\text { total number of companies }} * 100$

Group D includes companies that are on the curve of financial distress but are, in fact, financially healthy. However, this fact does not represent a significant problem from the point of view of the application, as the result of the diagnostics caused by the increased interest in the financial situation of the company does not bring negative consequences for the interested parties of the company. The production possibility curve in the second step (grey zone) in 2013 (2014, 2015, $2016,2017)$ was formed by $19.09 \%$ (10.91\%, $9.09 \%, 6.36 \%, 9.09 \%$ ) of companies, which was calculated as

percentage of companies that create the production possibility curve in second step

$$
=\frac{\text { number of companies in group } B+\text { group } E}{\text { total number of companies }} * 100
$$

\begin{tabular}{|c|c|c|c|c|}
\hline Indicators & $\begin{array}{c}\text { Mann-Whitney test } \\
\text { (p-value) }\end{array}$ & $\begin{array}{l}\text { Average of financially } \\
\text { health companies }\end{array}$ & $\begin{array}{l}\text { Average of companies } \\
\text { in financial distress }\end{array}$ & Input / Output \\
\hline Net debt & 0.00000 & -250723.11 & -37258.57 & output \\
\hline Total insolvency & 0.00002 & 0.92 & 1.29 & output \\
\hline Return on long-term capital (EBIT) & 0.00000 & 0.40 & 0.13 & input \\
\hline Repayment period of liabilities & 0.00679 & 152.05 & 173.49 & output \\
\hline $\begin{array}{l}\text { Repayment period of liabilities } \\
\text { in relation to sales }\end{array}$ & 0.00137 & 73.19 & 81.62 & output \\
\hline Effective tax rate & 0.00000 & 0.25 & 0.19 & input \\
\hline $\begin{array}{l}\text { Coverage of personnel costs } \\
\text { and depreciation }\end{array}$ & 0.00000 & 1.29 & 1.04 & input \\
\hline
\end{tabular}

Source: Own calculations 
This second curve represents a zone with a lower degree of risk and represents the possibility of financial problems in the following year. The model correctly included up to $73.64 \%$ $(84.55 \%, 84.55 \%, 84.55 \%, 82.73 \%)$ of financially healthy companies in the financial health zone, which was calculated as

percentage of companies that create the production possibility curve in second step

$=\frac{\text { number of companies in group } C+\text { group } F}{\text { total number of companies }} * 100$

According to this model, these companies are outside the threat of financial distress.

\begin{tabular}{|c|c|c|c|c|c|}
\hline & $\mathbf{2 0 1 3}$ & $\mathbf{2 0 1 4}$ & $\mathbf{2 0 1 5}$ & $\mathbf{2 0 1 6}$ & $\mathbf{2 0 1 7}$ \\
\hline $\mathbf{A}$ & 3 & 1 & 2 & 4 & 3 \\
\hline & $2.73 \%$ & $0.91 \%$ & $1.82 \%$ & $3.64 \%$ & $2.73 \%$ \\
\hline $\mathbf{B}$ & 6 & 2 & 2 & 1 & 2 \\
\hline & $5.45 \%$ & $1.82 \%$ & $1.82 \%$ & $0.91 \%$ & $1.82 \%$ \\
\hline $\mathbf{C}$ & 1 & 7 & 6 & 5 & 5 \\
\hline & $0.91 \%$ & $6.36 \%$ & $5.54 \%$ & $4.55 \%$ & $4.55 \%$ \\
\hline $\mathbf{D}$ & 5 & 4 & 5 & 6 & 6 \\
\hline & $4.55 \%$ & $3.64 \%$ & $4.55 \%$ & $5.45 \%$ & $5.45 \%$ \\
\hline $\mathbf{E}$ & 15 & 10 & 8 & 6 & 8 \\
\hline & $13.64 \%$ & $9.09 \%$ & $7.27 \%$ & $5.45 \%$ & $7.27 \%$ \\
\hline $\mathbf{F}$ & 80 & 86 & 87 & 88 & 86 \\
\hline & $72.73 \%$ & $78.18 \%$ & $79.09 \%$ & $80.00 \%$ & $78.18 \%$ \\
\hline$\Sigma$ & 110 & 110 & 110 & 110 & 110 \\
\hline $\mathbf{I}_{\mathbf{C C}}$ & $75.45 \%$ & $79.09 \%$ & $80.09 \%$ & $83.64 \%$ & $80.91 \%$ \\
\hline $\mathbf{I}_{\mathbf{N C}}$ & $19.09 \%$ & $10.91 \%$ & $9.09 \%$ & $6.36 \%$ & $9.09 \%$ \\
\hline $\mathbf{I}_{\mathbf{I C}}$ & $5.45 \%$ & $10.00 \%$ & $10.00 \%$ & $10.00 \%$ & $10.00 \%$ \\
\hline
\end{tabular}

Source: Own calculations

Table 3: Results of diagnosing the financial health of Slovak ICT companies.

To assess the overall classification ability of the model can be evaluated based on the mentioned indices, the index of correct classification, the index of neutral classification and the index of incorrect classification.

In $2013(2014,2015,2016,2017)$ the model correctly classified $83(87,89,92,89)$ companies from the total set of 110 companies, which in a percentage expression represents $75.45 \%$ $(79.09 \%, 80.09 \%, 83.64 \%, 80.91 \%)$. The index of correct classification achieves relatively satisfactory results in all years. Using the parameters shown in Table 2 to the model, DEA showed a relatively high percentage. Therefore, we propose the use of these indicators to analyse the financial health of IT companies in the long term using the DEA method.
The index of neutral classification indicates the ratio of companies that were included in the grey zone. Companies in the grey zone are characterized by a certain degree of risk of over-indebtedness, but lower compared to the financial distress zone. The value of the index of neutral classification ranges from $6.36 \%$ to $19.09 \%$ in the observed years. It can be stated that in the grey zone, financially healthy companies significantly prevail over companies in financial distress for all years.

The incorrect classification index reached 5.45\% in 2013 and in the other years $(2014,2015,2016$, 2017 ) it reached the level of $10 \%$, which means that the model in $2013(2014,2015,2016,2017)$ incorrectly classified six companies in 2013 and 11 companies in other years.

Delina and Packová (2013) in their study dealt with the validation of selected models (Altman's Z-score, Beerman's discriminant function - Bonity Index and IN05 Index) on real data of companies established in Slovakia in the period 1993-2007, while they developed new modified model while using regression analysis to get higher predictive performance on analysed sample than chosen models. Compared to the traditional models used in this study, the error rate of the DEA model we used is not so high (The Altmans Z-score was $87.62 \%$, the Bonity Index was $78.02 \%$ and the IN05 was $85.41 \%$ ), and therefore we can consider the DEA model to be suitable for application in the conditions of ICT companies in Slovakia.

At first sight, the results of this model are satisfactory, but if we look at the number of companies included in group A (enterprises in financial distress classified as financial distress) so we see that out of the total number of 10 companies classified in the financial distress zone according to equity, in 2013 (2014, 2015, $2016,2017)$ only $3(1,2,4,3)$ companies were included in this category, which in neither of these years nor $50 \%$ of the total number of companies in financial distress. Such a relatively high error rate of the model is considered a high risk in terms of possible consequences and potential costs of neglecting financial distress signals.

As mentioned in the literature review chapter, it is crucial for a company which wants to apply for a loan to assess its financial situation and be financially healthy (low credit risk). If it is located in the grey zone (greater credit risk), it should take steps not to be at risk of failure and to be included in the financial health zone in the next period. 
The worst option is if the company is included in the financial default zone because at that time it poses a significant credit risk for the bank, which is why the bank does not approve the loan.

\section{Conclusion}

Data Envelopment Analysis is increasingly being used in various areas of finance, health sector, agricultural sector and others. This article dealt with its use in the evaluation of the financial health of a selected sample of companies in the period 2013 to 2017, and consequently, the credit risk they may pose to financial entities. Mainly, we have applied the ADD DEA model and evaluated the classification indexes of this model. As the main contribution of the work, we consider the proposal of specific financial indicators for the analysis of the financial health of companies in the ICT sector in a multi-year period using the DEA model. We justify the choice of these indicators by the relatively high success of the DEA model, in which these indicators were used as inputs and outputs. The paper can also serve as a methodological approach to evaluating the financial health of companies through the DEA model, regardless of the industry. The paper can also serve as additional teaching material on the issue of using DEA to evaluate the financial health of the company.

The results show that DEA achieves a satisfactory value of a correct classification into the relevant zone (financial health zone, grey zone, financial distress zone). On the other hand, the relatively high error rate of the DEA model in the identification of companies in financial distress encourages the discussion of the adequacy and appropriateness of using DEA in diagnosing the financial health of companies in real conditions. We believe that one of the possible factors that could negatively affect the classification accuracy of the used DEA model is the structure of the data set. In the years, which we have analysed, the ratio between financially healthy companies and companies in financial distress was 10: 1. This low $9 \%$ ratio of financially distressed companies in the dataset may have led the DEA to identify with its error rate a small percentage of the total number of financially distressed companies included in the analysis. In our opinion, this was the fact that greatly influenced the results and seemingly degraded the ability of the DEA model used. We assume that a higher ratio of companies in financial distress in the data set will, on the contrary, favour the classification capacity of the DEA, so that the DEA will be able to correctly classify a higher percentage of companies in the financial distress zone.

The method applied by us is suitable for application in other sectors of the national economy. An example is the agro-sector, where this method can also be used by agro-policy makers in evaluating the financial health of companies, which is part of the decision to provide funds. It is on the basis of the use of this method that it is possible to achieve that the provided state or EU funds are spent efficiently.

It mentioned perspective regarding the increase of the classification ability of the proposed DEA model as well as the comparison of this alternative method with the traditional models used to evaluate the financial health of the company, such as Altman's Z-score, Zmijewski's X-score, IN 05 or Quick test for different industries, are the basis for our further research in the future. We also want to research whether there is a link between the performance at the operational (cost-oriented) and financial (profit-oriented) spaces of the Slovak company as described by Tsolas (2015) on Greek companies. The aim will be to determine whether the company's profit is the driving force of its success in the industry and to analyse the operating performance efficiency of Slovak companies in the sample but also to assess their performance in earnings and cash flow generation.

\section{Acknowledgements}

This paper was supported by VEGA project No. $1 / 0794 / 18$.

Corresponding authors

Assoc. prof. Kristína Kočišová, PhD.

Department of Banking and Investments, Faculty of Economics, Technical University of Košice

Nèmcovej 32, 04001 Košice, Slovak Republic

E-mail:kristina.kocisova@tuke.sk

ORCID: 0000-0003-0784-441X 


\section{References}

[1] AlAli, M., AlShamali, M., AlAwadhi, K. and AlSabah, A. (2018) "The use of Zmijewski model in examining the financial soundness of oil and gas companies listed at Kuwait Stock Exchange", International Journal of Economics, Commerce and Management Research Studies, Vol. 1, No. 2, pp. 15-21. ISSN 2456-2165.

[2] Alin, A. (2010) "Multicollinearity“, Wiley Interdisciplinary Reviews: Computational Statistics, Vol. 2010, No. 2-3., pp. 370-374. ISSN 1939-5108. DOI 10.1002/wics.84.

[3] Altman, E. I. (1968) "Financial Ratios, Discriminant Analysis and the Prediction of Corporate Bankruptcy“, Journal of Finance, Vol. 23, No. 4, pp. 589-609. ISSN 00221082. DOI 10.2307/2978933.

[4] Aminian, A., Mousazade, H. and Khoshkho, O. I. (2016) "Investigate the ability of bankruptcy prediction models of Altman and Springate and Zmijewski and Grover in Tehran Stock Exchange“, Mediterranean Journal of Social Sciences, Vol. 7, No. 4 S1, pp. 208. ISSN 2039-2117. DOI 10.5901/mjss.2016.v7n4S1p208.

[5] Bandyopadhyay, A. (2007) "Credit risk models for managing bank's agricultural loan portfolio“, Munich Personal RePEc Archive.

[6] Banker, R. D., Charnes, A. and Cooper, W.W. (1984) "Some Models for Estimating Technical Scale Inefficiencies in Data Envelopment Analysis“, Management Science, Vol. 30, No. 9, pp. 1078-1092. ISSN 1526-5501. DOI 10.1287/mnsc.30.9.1078.

[7] Bányiová, T., Bieliková, T. and Piterková, A. (2014) "Prediction of agricultural enterprises distress using data envelopment analysis", Proceedings of the $11^{\text {th }}$ International Scientific Conference European Financial Systems, Masaryk University, Brno, pp. 18-25. ISBN: 978-80-210-7153-7.

[8] Beaver, W. H. (1966) "Financial ratios as predictors of failure“, Journal of Accounting Research, Vol. 30, No. 9., pp. 71-111. E-ISSN 1526-5501, ISSN 0025-1909. DOI 10.2307/2490171.

[9] Bod'a, M. and Úradníček, V. (2019) "Predicting Financial Distress of Slovak Agricultural Enterprises“, Ekonomický časopis, Vol. 67, No. 4, pp. 426-452. ISSN 0013-3035.

[10] Bogetoft, P. and Otto, L. (2011) "Additional Topics in DEA", In: Benchmarking with DEA, $S F A$, and R. International Series in Operations Research \& Management Science, Vol. 157, Springer, New York, NY. ISBN 978-1-4419-7960-5, E-ISBN 978-1-4419-7961-2. DOI 10.1007/978-1-4419-7961-2_5.

[11] Brewer, B. E., Wilson, C. A., Featherstone, A. M., Harris, J. M., Erickson, K. and Hallahan, C. (2012) "Measuring the financial health of US production agriculture", Journal of ASFMRA, pp. 178-193. ISSN 0003116X.

[12] Delina, R. and Packová, M. (2013) "Validácia predikčnýchch bankrotových modelov v podmienkach SR“, E+ M Ekonomie a management, Vol. 2013, No. 3, p. 101-112. ISSN 2336-5604. (in Slovak).

[13] Ékes, K. S. and Koloszár, L. (2014) "The efficiency of bankruptcy forecast models in the Hungarian SME sector“, Journal of Competitiveness, Vol. 6, No. 2, pp. 56-73. ISSN 1804-1728. DOI 10.7441/joc.2014.02.05.

[14] Fakhri Husein, M. and Tri Pambekti, G. (2014) "Precision of the models of Altman, Springate, Zmijewski, and Grover for predicting the financial distress", Journal of Economics, Business, and Accountancy Ventura, Vol. 17, No. 3, pp. 405-416. ISSN 2087-3735. DOI 10.14414/jebav.14.1703010.

[15] Feruś, A. (2008) "The DEA method in managing the credit risk of companies“, Ekonomika,Vilnjus University Press, E-ISSN 1392-1258, ISSN 2424-6166 Vol. 2008, No. 84. [Online]. Available: http://www.journals.vu.lt/ekonomika/article/view/5126/3383. ISSN 1392-1258. [Accessed: 4 Jan. 2020].

[16] Grover, J. and Lavin, A. (2001) "Financial Ratios, Discriminant Analysis and The Prediction of Corporate Bankruptcy: a Service Industry Extension of Altman's Z-Score Model of Bankruptcy Prediction“, Working Paper. Southern Finance Assosiation Annual Meeting. 
[17] Hart, A. (2001) "Mann-Whitney test is not just a test of medians: differences in spread can be important”, BMJ, Vol. 323, No. 7309, pp. 391-393. ISSN 0959-8138, 1756-1833, 0959-8138, 1756-1833, 0007-1447, 0267-0623. DOI 10.1136/bmj.323.7309.391.

[18] Horváthová, J., Mokrišová, M. and Vrábliková, M. (2019) "Integration of balanced scorecard and data envelopment analysis to measure and improve business performance“, Management Science Letters, Vol. 9, No. 9. ISSN 1321-1340. DOI 10.5267/j.msl.2019.5.017.

[19] Charnes, A., Cooper, W. W. and Rhodes, E. (1978) "Measuring the Efficiency of Decision Making Units“, European Journal of Operational Research, Vol. 2, No. 6, pp. 429-444. ISSN 0377-2217. DOI 10.1016/0377-2217(78)90138-8.

[20] Charnes, A., Cooper, W. W., Golany, B., Seiford, L. M. and Stutz, J. (1985) "Foundations of Data Envelopment Analysis for Pareto-Koopmans Efficient Empirical Production Functions“, Journal of Econometrics, Vol. 30, No. 12, pp. 91-127. ISSN 0304-4076. DOI 10.1016/0304-4076(85)90133-2.

[21] Chaudhuri, A. and Ghosh, S. K. (2017) "Bankruptcy prediction through soft computing based deep learning technique“, Springer. ISBN 978-981-10-6683-2.

[22] James, G., Witten, D., Hastie, T. and Tibshirani, R. (2013) "An introduction to statistical learning“, New York: Springer, Vol. 112, pp. 3-7. ISBN 978-1-4614-7137-0.

[23] Janová, J., Vavřina, J. and Hampel, D. (2012) "DEA as a tool for bankruptcy assessment: the agribusiness case study“, Proceedings of the $30^{\text {th }}$ International Conference Mathematical Methods in Economics, Vol. 2012, pp. 379-383. ISBN 978-80-7248-779-0.

[24] Jedik, A. and Stalgienè, A. (2018) "The likelihood of farms bankrupcy: The case of Lithuanian family farms“", Management Theory and Studies for Rural Business and Infrastructure Development, Vol. 40, No. 2, pp. 198-205. E-ISSN 2345-0355. DOI 10.15544/mts.2018.19.

[25] Káčer, M., Ochotnický, P. and Alexy, M. (2019) "The Altman's Revised Z'-Score Model, Nonfinancial Information and Macroeconomic Variables: Case of Slovak SMEs“, Ekonomický časopis, Vol. 67, No. 4, pp. 335-366. ISSN 0013-3035.

[26] Karas, M., Reznakova, M. and Pokorny, P. (2017) "Predicting bankruptcy of agriculture companies: Validating selected models“, Polish Journal of Management Studies, Vol. 15, No. 1. ISSN 2081-7452. DOI 10.17512/pjms.2017.15.1.11.

[27] Kassambara, A. (2018) "Machine Learning Essentials: Practical Guide in R“, STHDA, p. 209. ISBN 9781986406857.

[28] Kiaupaite-Grushniene, V. (2016, December) "Altman Z-score model for bankruptcy forecasting of the listed Lithuanian agricultural companies", $5^{\text {th }}$ International Conference on Accounting, Auditing, and Taxation (ICAAT 2016), Atlantis Press. ISBN 978-94-6252-261-9. ISSN 2352-5428. DOI 10.2991/icaat-16.2016.23.

[29] Kotulič, R., Király, P. and Rajčániová, M. (2007) "Finančná analýza podniku“, Bratislava, Iura Edition, p. 206. ISBN 978-80-8078-117-0. (in Slovak).

[30] Kralicek, P. (1993) "Základy finančního hospodaření“, Prague, Linde, p. 110, ISBN 80-85647. (in Czech).

[31] Krausová, A. (2018) "Abuse of market power in ICT sector“, The Lawyer Quarterly, Vol. 8, No. 1, pp. 78-81. ISSN 1805-840X.

[32] Mann, H. B. and Whitney, D. R. (1947) "On a test of whether one of two random variables is stochastically larger than the other”, The Annals of Mathematical Statistics, Vol. 18, No. 1, pp. 50-60. ISSN 00034851.

[33] McKnight, P. E. and Najab, J. (2010) "Mann-Whitney U Test", In: The Corsini Encyclopedia of Psychology. E-ISBN 9780470479216, ISBN 9780470170243. DOI 10.1002/9780470479216. 
[34] Mendelová, V. and Bieliková, T. (2017) "Diagnostikovanie finančného zdravia podnikov pomocou metódy DEA: Aplikácia na podniky v Slovenskej republike“, Politická ekonomie, Vol. 2017, No. 1, pp. 26-44. ISSN 23368225. DOI 10.18267/j.polek.1125. (in Slovak)

[35] Paradi, J. C., Asmild, M. and Simak, P. C. (2004) "Using DEA and Worst Practice DEA in Credit Risk Evaluation“, Journal of Productivity Analysis, Vol. 21, No. 2, pp. 153-165. ISSN 0895562X. DOI 10.1023/B:PROD.0000016870.47060.0b.

[36] Sueyoshi, T. and Goto, M. (2009) "Methodological Comparison Between DEA (Data Envelopment Analysis) and DEA-DA (Discriminant Analysis) from the Perspective of Bankruptcy Assessment", European Journal of Operational Research, Vol. 199, No. 2, pp. 561-575. ISSN 03772217. DOI 10.1016/j.ejor.2008.11.030.

[37] Tone, K. (2001) "A Slacks-Based Measure of Efficiency in Data Envelopment Analysis", European Journal of Operational Research, Vol. 130, No. 3, pp. 498-509. ISSN 03772217. DOI 10.1016/s0377-2217(99)00407-5.

[38] Vaněk, J., Jarolímek, J. and Vogeltanzová, T. (2011) "Information and Communication Technologies for Regional Development in the Czech Republic - Broadband Connectivity in Rural Areas", Agris on-line Papers in Economics and Informatics, Vol. 3, No. 3, pp. 67-76. ISSN 1804-1930.

[39] Vavřina, J., Hampel, D., and Janová, J. (2013) "New approaches for the financial distress classification in agribusiness", Acta Universitatis Agriculturae et Silviculturae Mendelianae Brunensis, Vol. 61, No. 4, pp. 1177-1182. E-ISSN 2464-8310, ISSN 1211-8516. DOI 10.11118/actaun201361041177.

[40] Wilcoxon, F. (1945) "Individual comparisons by ranking methods", In: Breakthroughs in Statistics, pp. 196-202. ISBN 978-1-4612-4380-9. DOI 10.1007/978-1-4612-4380-9_16.

[41] Xin, A. L. J., Hoe, L. W. and Siew, L. W. (2019) "An empirical evaluation on the credit risk efficiency of financial institutions in Malaysia with data envelopment analysis model", AIP Conference Proceedings, Vol. 2138, No. 1. DOI 10.1063/1.5121102.

[42] Zhao, J., Barry, P. J. and Katchova, A. L. (2008) "Signaling credit risk in agriculture: implications for capital structure analysis“, Journal of Agricultural and Applied Economics, Vol. 40, No. 3. pp. 805-820. ISSN 1074-0708. DOI 10.1017/S1074070800002340. 